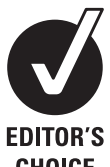

CHOICE

\title{
Therapeutic hypothermia in the emergency department following out-of-hospital cardiac arrest
}

\author{
R M Lyon, C E Robertson, G R Clegg
}

Emergency Department, Royal Infirmary of Edinburgh, Edinburgh, UK

\section{Correspondence to}

Dr Richard M Lyon, Emergency Department, Royal Infirmary of Edinburgh, 51 Little France Crescent, Edinburgh EH16 4SA, UK; richardlyon@doctors.org.uk

Accepted 9 February 2010

\section{ABSTRACT}

Out-of-hospital cardiac arrest (OHCA) is a leading cause of mortality and severe neurological disability. Recent literature suggests that mild therapeutic hypothermia (MTH) can improve survival and neurological outcome in some groups of comatose patients after cardiac arrest but uncertainty exists over the best way to implement this treatment. This review examines the evidence for the efficacy and mode of implementation of MTH after OHCA, particularly in the Emergency Department setting. A literature search was performed and all systematic reviews; human and animal randomised and nonrandomised trials were screened for inclusion. Specific emphasis was placed on MTH being commenced in the prehospital and Emergency Department setting. Outcome measures were: time to reach target temperature, in-hospital mortality, neurological outcome at hospital discharge and complications of therapeutic hypothermia. Two systematic reviews found that MTH improved outcome after OHCA. Five human randomised controlled trials were identified. Two trials commenced cooling prehospital. One showed a favourable outcome but the other failed to show survival benefit. The other three trials only commenced cooling after the patient arrived in hospital and all showed improved survival for patients treated with MTH after OHCA. Evidence from animal and non-randomised studies suggests cooling should be commenced as early as possible after return of spontaneous circulation. Cold intravenous fluid was reported as a safe, effective means of cooling in the emergency setting. MTH improves patient outcome after OHCA. There is some evidence to suggest cooling should be commenced early. Cold intravenous crystalloid infusion may be the preferred cooling method in the Emergency Department.

\section{INTRODUCTION}

Out-of-hospital cardiac arrest (OHCA) is a leading cause of morbidity and mortality in the developed world. Resuscitation is attempted in 66 per 100000 population across Europe every year. Of those that survive to leave hospital, $>50 \%$ are left with permanent neurological sequelae. ${ }^{1}$ The first clinical intervention in the postresuscitation phase of OHCA shown to decrease mortality and improve neurological outcome is mild therapeutic hypothermia (MTH). ${ }^{2} \mathrm{MTH}$ was used in patients with OHCA as early as 1950, but cooling was largely abandoned due to complications. The concept of preserving the brain in the field, protecting it from hypoxia until the patient could be transported to hospital for spontaneous circulation to be restored or placed on cardiopulmonary bypass, was first suggested by Peter Safar in $1984 .{ }^{45}$ In the 1990s, a number of encouraging animal studies showed benefit, and several pilot human studies were conducted. $^{6} 7$ In 2002, two randomised trials demonstrated the benefit of cooling survivors of witnessed OHCA who had ventricular fibrillation (VF) as the presenting rhythm. ${ }^{2}{ }^{3}$ This led to the International Liaison Committee on Resuscitation, the American Heart Association and the European Resuscitation Council recommending MTH in the management of unconscious patients following OHCA. $^{8} 9$ Despite these recommendations, the use of MTH is not yet routine. ${ }^{10}$ Since 2002 , further trials have explored the use of MTH for non-VF $\mathrm{OHCA}$, traumatic cardiac arrests and in paediatric patients.

The optimum initiation, method and duration of cooling are unclear. ${ }^{11}$ Animal research suggests that cooling early after return of spontaneous circulation (ROSC) is associated with improved neurological outcome, ${ }^{12}{ }^{13}$ but human studies show that delayed cooling also yields favourable results. $^{3} 1214$

Both invasive and non-invasive cooling methods have been developed, and whole-body and brainonly cooling methods have been trialled. The majority of cooling techniques have been trialled in critical care settings with few methods specifically evaluated in the Emergency Department (ED). ${ }^{15}$ While MTH initiated in the ED may reduce the time taken to reach target temperature, prehospital cooling poses logistical and technical challenges. Patients arriving at hospital after OHCA may require in-hospital transfer for imaging or cardiac intervention prior to ICU (intensive care unit) admission. Cooling techniques intended for early deployment must therefore combine efficacy with ease of use.

While some ambulance services and EDs have adopted MTH as a routine treatment for patients after OHCA, it is unclear whether the available evidence supports this practice.

This paper aims to review and discuss key elements of the published literature on using MTH in the emergency setting and is not intended to provide a definite statement in the form of a systematic review.

We reviewed the published literature to answer the following:

1. In comatose patients after OHCA, does MTH improve neurological outcome?

2. Is there an optimal time and place for commencing MTH?

3. In patients after OHCA considered for MTH, what methods of cooling are available for use within the ED? 


\section{METHODS}

A literature review was performed by a single investigator. All short-listed studies were assessed by the other two authors for quality and to ensure the inclusion criteria were met. Search terms included 'therapeutic hypothermia', 'hypothermia', 'cardiac arrest', 'heart arrest', 'out-of-hospital cardiac arrest' and 'cardiopulmonary resuscitation'. Outcome parameters included in-hospital mortality, 6-month mortality and favourable neurological outcome (defined as independent living) within 6 months.

Inclusion criteria were studies commencing cooling early post-ROSC. For human studies we included those commencing cooling prehospital or in the ED. For animal studies we included cooling before, during or immediately after cardiac arrest. Specific exclusion criteria included non-cardiac arrest conditions-for example, myocardial infarction, cerebrovascular accident and traumatic brain injury. In contrast to previous published systematic reviews, ${ }^{16} 17$ this review specifically examines MTH use in the prehospital and ED setting. We found the number of randomised controlled trials (RCTs) on the use of MTH after OHCA to be small; therefore, all RCTs were screened for inclusion, regardless of the timing of initiation of cooling.

We included literature searches from Ovid Medline 1950-2009, the Cochrane Library, EMBASE 1988-2009, Google scholar and citation tracking. The search sought to identify studies that evaluated the use of MTH following OHCA using the search criteria above. Finally, a Web of Science citation search was performed on all included studies. Reference lists of all available primary studies and review articles were obtained to identify potentially relevant citations. Previously published systematic review articles were sought, looking for particular relevance to using $\mathrm{MTH}$ in the prehospital and ED setting. After a generalised search, limits were applied for 'trials'.

Human trials were assessed using the Jadad system ${ }^{18}$ to assess internal validity. This allows a measure of comparison of quality between trials.

\section{RESULTS}

One thousand and sixty-two papers were screened for inclusion. These were subdivided into animal studies, non-randomised studies, randomised trials and systematic reviews. Two systematic reviews and five randomised clinical trials were identified. Five animal trials comparing timing of cooling initiation were included.

\section{Animal studies}

The first animal studies using hypothermia after cardiac arrest were reported in the 1950s. In the early 1960s, Peter Safar observed that dogs that were mildly hypothermic at the initiation of experimental cardiac arrest had a better neurological outcome than dogs that were normothermic. ${ }^{19}$

A summary of selected animal studies is shown in table 1. These particularly relate to early cooling and the potential effect this may have on outcome.

The discovery of the neuroprotective effects of mild to moderate hypothermia led to the investigation of resuscitative hypothermia in several animal models. Dogs treated with immediate mild $\left(34^{\circ} \mathrm{C}\right)$ or moderate $\left(30^{\circ} \mathrm{C}\right)$ hypothermia showed improved functional and histological outcome. Dogs treated with deep hypothermia $\left(15^{\circ} \mathrm{C}\right)$, however, showed no improvement in neurological function and had more severe cerebral histological changes compared with mild or moderate hypothermia groups. ${ }^{13} 23$ In the same model, delaying the onset of cooling until 15 min postreperfusion was not associated with the same improvement in functional outcome but did improve histological damage. MTH was not associated with any significant side effects in these studies.

More recently a trend towards better outcomes after earlier initiation of therapeutic hypothermia ( $<15$ min post-ROSC) has been demonstrated. ${ }^{20} 22$ Kuboyama and colleagues demonstrated that survival without neurological deficit can still be achieved after 40 min of VF cardiac arrest in dogs when intra-arrest hypothermia is instigated using cold intravascular fluids. However, a delay in cooling after the induction of VF was

Table 1 Animal models of therapeutic hypothermia after out-of-hospital cardiac arrest

\begin{tabular}{|c|c|c|c|c|c|}
\hline Study (year) & Animal model & $\begin{array}{l}\text { Cooling method + target } \\
\text { temperature }\end{array}$ & Duration of cooling & Outcome & Comments \\
\hline Sterz $^{13}$ & $\begin{array}{l}30 \text { dogs. } 10 \text { min VF arrest model. } \\
\text { RCT of cooling during CPR vs } \\
\text { early post-ROSC cooling vs } \\
\text { normothermia }\end{array}$ & $\begin{array}{l}\text { Cooling externally } \\
34^{\circ} \mathrm{C}\end{array}$ & $20 \mathrm{~h}$ & $\begin{array}{l}\text { Improved neurological outcome } \\
\text { when cooling started during CPR } \\
\text { or immediately after ROSC }\end{array}$ & $\begin{array}{l}\text { External CPR and resuscitation } \\
\text { drugs used as per human practice }\end{array}$ \\
\hline Kuboyama ${ }^{20}$ & $\begin{array}{l}22 \text { dogs, induced VF for } 12.5 \text { min. } \\
\text { Prospective RCT of normothermia } \\
\text { vs immediate hypothermia vs } \\
\text { delayed ( } 15 \text { min after reperfusion) } \\
\text { cooling }\end{array}$ & $\begin{array}{l}\text { Cooling on bypass } \\
34^{\circ} \mathrm{C}\end{array}$ & $1 \mathrm{~h}$ & $\begin{array}{l}\text { Immediate cooling showed trend } \\
\text { towards better functional } \\
\text { outcome compared with delayed } \\
\text { cooling and associated with } \\
\text { lower histological damage scores }\end{array}$ & $\begin{array}{l}\text { Functional outcome did not reach } \\
\text { statistical significance }\end{array}$ \\
\hline Nozari $^{21}$ & $\begin{array}{l}27 \text { dogs. VF cardiac arrest model } \\
\text { with } 40 \text { min no-flow time. RCT of } \\
\text { normothermia vs mild } \\
\text { hypothermia vs moderate } \\
\text { hypothermia }\end{array}$ & $\begin{array}{l}\text { Cooling with venovenous } \\
\text { extracorporeal shunt } \\
34^{\circ} \mathrm{C}\end{array}$ & $12 \mathrm{~h}$ & $\begin{array}{l}\text { Mild or moderate hypothermia } \\
\text { during prolonged CPR improved } \\
\text { survival and functional outcome }\end{array}$ & $\begin{array}{l}\text { Invasive techniques used; not } \\
\text { easily applicable to humans }\end{array}$ \\
\hline Abella 22 & $\begin{array}{l}30 \text { mice. Potassium-induced } \\
\text { arrest. Prospective RCT of intra- } \\
\text { arrest cooling vs delayed } \\
\text { ( } 20 \text { min) postarrest cooling vs } \\
\text { normothermia }\end{array}$ & $\begin{array}{l}\text { Cooling with cooling } \\
\text { blanket } \\
30^{\circ} \mathrm{C}\end{array}$ & $1 \mathrm{~h}$ & $\begin{array}{l}\text { Intra-arrest cooling showed } \\
\text { better survival to } 72 \mathrm{~h} \text { than } \\
\text { delayed cooling or normothermia }\end{array}$ & $\begin{array}{l}\text { Results statistically significant. } \\
\text { Only asystolic arrests. }\end{array}$ \\
\hline Zhao $^{12}$ & $\begin{array}{l}45 \text { mice. Potassium-induced } \\
\text { cardiac arrest for } 8 \text { min. } \\
\text { Prospective RCT of normothermia } \\
\text { vs intra-arrest cooling vs } \\
\text { prolonged resuscitation }(9.5 \mathrm{~min}) \\
\text { to initiate cooling }\end{array}$ & $\begin{array}{l}\text { Cooling with cooling } \\
\text { blanket } \\
30^{\circ} \mathrm{C}\end{array}$ & $90 \mathrm{~s}$ & $\begin{array}{l}\text { Animals treated with } \\
\text { hypothermia, even in prolonged } \\
\text { ischaemia group showed } \\
\text { improved survival compared with } \\
\text { normothermic controls. } \\
\text { Haemodynamic variables also } \\
\text { improved. }\end{array}$ & $\begin{array}{l}\text { Results statistically significant. } \\
\text { Early intra-arrest cooling possible } \\
\text { only in prehospital setting. Intra- } \\
\text { arrest cooling may be useful for } \\
\text { haemodynamic resuscitation }\end{array}$ \\
\hline
\end{tabular}


associated with an increased mortality and poorer neurological outcomes. ${ }^{20}$ Nozari showed that early intra-arrest cooling in dogs with 60 min of VF resulted in a favourable neurological outcome. ${ }^{21}$ However, when cooling was delayed until 20 min after onset of VF, seven of eight dogs did not survive. Abella and colleagues showed that mice cooled 20 min after cardiac arrest showed a higher mortality than mice cooled just prior to resuscitation from an 8 min period of cardiac arrest. ${ }^{22}$ Zhao demonstrated in a randomised, controlled, murine model that delaying resuscitation to institute therapeutic hypothermia still resulted in a favourable neurological outcome. ${ }^{12}$

The animal studies reviewed suggest that cooling should commence with a minimum of delay after cardiac arrest and should continue for at least $24 \mathrm{~h}$ to confer lasting neuroprotection.

\section{Non-randomised trials}

The first reported human studies using therapeutic hypothermia were reported in $1958 .^{24}$ Since then $>20$ non-randomised studies have been published. The target temperature has consistently been $32-34^{\circ} \mathrm{C}$ using a variety of cooling techniques. Reported favourable neurological outcome rates vary from $25 \%$ to $68 \%$. A summary of non-randomised trials is shown in table 2 .

In 1997, Bernard and colleagues conducted a pilot study comparing patients treated with $\mathrm{MTH}$, induced by the application of ice packs, with normothermic controls. They demonstrated improved outcome in the treatment group, without significant complications. ${ }^{6}$ Yanagawa cooled 13 patients who had survived initial resuscitation. ${ }^{7}$ Cooling to $33^{\circ} \mathrm{C}$ commenced on arrival at the $\mathrm{ED}$ (time to target temperature of $5.5 \mathrm{~h}$ postROSC) and was maintained for $48 \mathrm{~h}$ before slowly rewarming at $1^{\circ} \mathrm{C}$ per day.

Further studies adopted progressively more sophisticated means of inducing therapeutic hypothermia. A study using cold air surface cooling in the ED by Zeiner and colleagues was successful in lowering core body temperature. ${ }^{25}$ Despite nonsignificant results, these studies supported the evidence that MTH was a safe clinical intervention and could improve outcome after OHCA.

Cooling modalities are summarised in table 3. Methods of initiating prehospital cooling have been investigated, with cold fluids and ice packs being the modalities of choice. ${ }^{28} 29$ Other methods of cooling, including body surface cooling with ice and cold blankets, helmet devices, endovascular cooling catheters, haemofiltration and coronary bypass, have been studied. None of these combines efficacy with ease of use. A key finding is that infusion of up to 2 litres of cold $\left(4^{\circ} \mathrm{C}\right)$ intravenous fluid $(0.9 \%$ saline or Ringer's lactate) in the immediate post-ROSC phase is an effective and safe method of cooling and is not associated with significant complications or cardiovascular instability. Whatever the cooling technique employed the degree of hypothermia induced is important, and Merchant and colleagues have demonstrated that overcooling is a significant risk and careful core body temperature monitoring is mandatory. ${ }^{30}$ The risks of overcooling include infection, coagulopathy and cardiac arrhythmias.

\section{Randomised trials}

Five randomised clinical trials of therapeutic hypothermia postIHCA have been published. ${ }^{2} 32-34$ These are summarised in table 4 . The first clinical trial of therapeutic hypothermia, published in 2001, ${ }^{32}$ enrolled 30 patients following OHCA with asystole or pulseless electrical activity (PEA) as the initial cardiac rhythm. Sixteen patients were cooled to $34^{\circ} \mathrm{C}$ for a maximum of $4 \mathrm{~h}$ with a helmet cooling device and then allowed to rewarm passively. Two of the patients treated with MTH survived with a favourable neurological outcome compared with no patients in the normothermia group.

In 2002, two prospective, RCTs of MTH in the postresuscitation management of witnessed OHCA were published. ${ }^{23}$

Table 2 Non-randomised studies

\begin{tabular}{|c|c|c|c|c|c|c|}
\hline Study & Year & $\begin{array}{l}\text { Initial cardiac } \\
\text { rhythm }\end{array}$ & $\begin{array}{l}\text { Cooling method }+ \text { target } \\
\text { temperature }\end{array}$ & $T_{\text {targ }}(\min )$ & Duration of cooling & Outcomes \\
\hline $\begin{array}{l}\text { Bernard }^{6} \\
(\mathrm{n}=22)\end{array}$ & 1997 & Any & $\begin{array}{l}\text { Ice packs } \\
33^{\circ} \mathrm{C}\end{array}$ & 74 & $12 \mathrm{~h}$ & $\begin{array}{l}\text { No significant side effects. Increased } \\
\text { survival and better neurological outcome } \\
\text { compared with historical controls }\end{array}$ \\
\hline $\begin{array}{l}\text { Yanagawa }^{7} \\
(\mathrm{n}=13)\end{array}$ & 1998 & Any & $\begin{array}{l}\text { Cooling blanket } \\
33-34^{\circ} \mathrm{C}\end{array}$ & 414 & $48 \mathrm{~h}$ & $\begin{array}{l}\text { Cooling associated with increased rates of } \\
\text { pneumonia. Higher survival and recovery } \\
\text { rates in hypothermia group }\end{array}$ \\
\hline $\begin{array}{l}\text { Zeiner }^{25} \\
(\mathrm{n}=27)\end{array}$ & 2000 & Any & Cold air & 276 & $>24 \mathrm{~h}$ & $\begin{array}{l}\text { No major complications in first } 24 \mathrm{~h} \text {. Mild } \\
\text { resuscitative hypothermia shown to be } \\
\text { safe and feasible }\end{array}$ \\
\hline $\begin{array}{l}\text { Felberg }^{26} \\
(\mathrm{n}=9)\end{array}$ & 2001 & Any & Cooling blanket & 378 & $24 \mathrm{~h}$ & $\begin{array}{l}\text { No major complications. Cooling methods } \\
\text { found to be slow and imprecise. } \\
\text { Favourable neurological outcome } \\
\text { demonstrated }\end{array}$ \\
\hline $\begin{array}{l}\text { Bernard }^{27} \\
(\mathrm{n}=22)\end{array}$ & 2003 & Any & $\begin{array}{l}\text { Cold fluids }\left(30 \mathrm{ml} / \mathrm{kg} 4^{\circ} \mathrm{C}\right. \\
\text { Ringer's), ice }\end{array}$ & ASAP & & $\begin{array}{l}\text { Rapid drop in core body temperature from } \\
35.5 \text { to } 33.8^{\circ} \mathrm{C} \text {, improved BP and renal } \\
\text { function. No cases of pulmonary oedema }\end{array}$ \\
\hline $\begin{array}{l}\operatorname{Kim}^{28} \\
(n=17)\end{array}$ & 2005 & Any & $\begin{array}{l}\text { Cold fluids ( } 2 \text { litres of } 4^{\circ} \mathrm{C} \\
\text { saline) }\end{array}$ & ASAP & $24 \mathrm{~h}$ & $\begin{array}{l}\text { Fluid infusion did not alter ejection } \\
\text { fraction, central venous pressure or } \\
\text { pulmonary pressures }\end{array}$ \\
\hline $\begin{array}{l}\text { Busch }^{29} \\
(\mathrm{n}=27)\end{array}$ & 2006 & Any & $\begin{array}{l}\text { Sports ice packs and water- } \\
\text { soaked towels placed } \\
\text { prehospital }\end{array}$ & 450 & $12-24 h$ & $\begin{array}{l}\text { Cooling rates found to be slow. Higher } \\
\text { in-hospital survival rates in cooled } \\
\text { patients }\end{array}$ \\
\hline $\begin{array}{l}\text { Merchant }^{30} \\
(\mathrm{n}=32)\end{array}$ & 2006 & Any & Cooling blanket & 360 & $12-24 \mathrm{~h}$ & $\begin{array}{l}\text { Majority of cases showed unintentional } \\
\text { overcooling to } \angle 32^{\circ} \mathrm{C}\end{array}$ \\
\hline $\begin{array}{l}\text { Kliegel }^{31} \\
(\mathrm{n}=20)\end{array}$ & 2007 & Any & Cold fluids $\left(4^{\circ} \mathrm{C}\right.$ saline $\left.30 \mathrm{ml} / \mathrm{kg} / \mathrm{h}\right)$ & 60 & $24 \mathrm{~h}$ & Majority reached $<34^{\circ} \mathrm{C}$ in $<60 \mathrm{~min}$ \\
\hline
\end{tabular}

ASAP, as soon as possible; BP, blood pressure; $T_{\text {targ, }}$ time to target temperature. 
Table 3 Cooling methods

\begin{tabular}{ll}
\hline Invasive techniques & Non-invasive techniques \\
\hline Cold intravenous fluid infusion & Ice packs \\
Extracorporeal cooling blood circuit & Cooling blankets (water/air filled) \\
$\quad$ Cardiopulmonary bypass & Cooling helmets (water/air filled) \\
Femoral-carotid bypass & Cold water immersion \\
Lavage & Self-adhesive cooling pads \\
Nasal/nasogastric/rectal/peritoneal & \\
Ice slush & \\
Endovascular cooling catheter & \\
\hline
\end{tabular}

Both of these studies recruited a highly selective cohort of patients, with $92 \%$ of patients initially assessed for eligibility excluded.

Recruitment criteria for both trials were similar and included ROSC in patients who remained intubated and ventilated after OHCA due to VF of presumed cardiac aetiology.

The European trial cooled 136 patients to a core temperature of $32-34^{\circ} \mathrm{C}$ using a mattress cover that delivered cold air. The aim was to reach target temperature within $4 \mathrm{~h}$ of ROSC, maintain it for $24 \mathrm{~h}$ and then allow passive rewarming to occur. The study showed the number needed to treat $(\mathrm{NNT})=6(\mathrm{RR} 1.40,95 \% \mathrm{CI}$ 1.08 to 1.81) for a favourable neurological outcome when MTH was used. The overall mortality at 6 months was reduced from $55 \%$ in the normothermia group to $41 \%$ in the $\mathrm{MTH}$ group, $\mathrm{NNT}=7$ (RR $40.74,95 \%$ CI 0.58 to 0.95 ).

In the Australian study cooling was initiated prehospital by applying ice packs to the head and torso. The target temperature $\left(33^{\circ} \mathrm{C}\right)$ was maintained for $12 \mathrm{~h}$ posthospital admission before patients were actively rewarmed after $18 \mathrm{~h}$. Forty-three patients were cooled; 21 (49\%) had a favourable neurological outcome of living at home or within a rehabilitation facility (RR $1.85,95 \%$ CI 0.97 to 3.49 , NNT=4). Mortality was reduced from $68 \%$ to $51 \%$ in the hypothermia group (RR 0.76 , $95 \%$ CI 0.52 to $1.10, \mathrm{NNT}=6$ ). These findings led to the European Resuscitation Council, in association with the International Liaison Committee on Resuscitation and the American Heart Association, recommending MTH as standard treatment for OHCA victims that achieve ROSC following a VF arrest. ${ }^{8}$

A randomised trial $^{33}$ of inducing $\mathrm{MTH}$ by isovolumic haemofiltration in patients after OHCA showed an increased survival benefit, but it was unclear whether this was conferred by the hypothermic or filtration processes. This technique is not suitable for use in the emergency and prehospital environment.

A recent clinical pilot study explored the benefit of cooling patients immediately after OHCA using intravenous cold saline administered by paramedics in the field. ${ }^{34}$ An infusion of $500-2000 \mathrm{ml}$ of $0.9 \%$ saline at $4^{\circ} \mathrm{C}$ was administered. Subsequent in-hospital cooling was at the discretion of the attending physician. Sixty-three patients were treated with prehospital hypothermia. Only 78\% of patients in the hypothermia group received further cooling. Prehospital cooling led to a significantly lower temperature on arrival at hospital $\left(34.7^{\circ} \mathrm{C}\right.$ vs $35.7^{\circ} \mathrm{C}$, $\mathrm{p}<0.0001)$. There was no significant difference in survival to hospital discharge in the hypothermia versus normothermia groups (33\% vs $29 \%, p=0.70)$. Subgroup analysis of patients with VF as the initial cardiac rhythm showed a trend towards increased survival to hospital discharge but there was a trend towards increased mortality in the cooling group where the initial cardiac rhythm was PEA or asystole.

\section{Systematic reviews}

Two systematic reviews matched our inclusion criteria. Cheung et al reviewed the combined data from four RCTs in 2006,

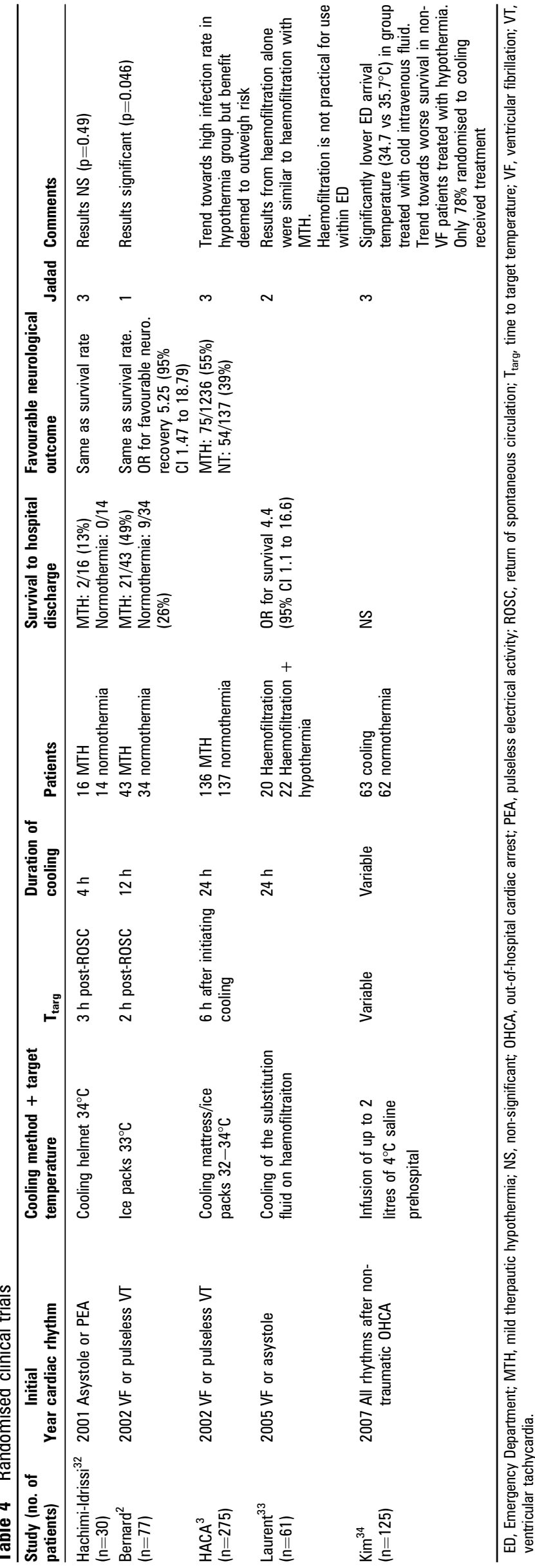

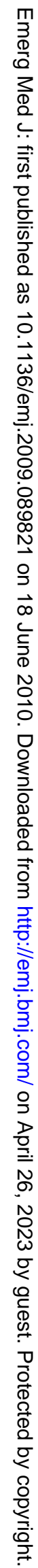


representing 436 patients. ${ }^{17}$ Inclusion criteria were adults with primary OHCA who remained comatose after ROSC. The clinical trials ranged from score 1 to 3 on the Jadad scale and $\mathrm{A}-\mathrm{C}$ on the Cochrane grade score. The combined data showed that MTH decreased in-hospital mortality (RR 0.75, 95\% CI 0.62 to 0.84). The review concluded that MTH had an NNT of 5 to improve neurological outcome and an NNT of 7 to save a life. However, the review failed to draw conclusions on the optimum cooling method, rate or duration of cooling. No evidence of treatment-limiting side effects was reported.

A meta-analysis ${ }^{16}$ of three trials has shown that patients treated with hypothermia show an increased rate of survival with favourable neurological outcome (RR 1.68, 95\% CI 1.29 to 2.07). The calculated $95 \%$ CI for the NNT to result in a patient being discharged from hospital with a favourable neurological outcome ranged from 4 to 13 .

\section{DISCUSSION}

There is strong evidence to support the use of MTH in comatose patients after OHCA whose initial cardiac rhythm was VF. The evidence supporting MTH use in other presenting cardiac rhythms is less clear and further studies are required. Despite animal studies demonstrating the benefit of immediate cooling, either during cardiopulmonary resuscitation (CPR) or immediately post-ROSC, ${ }^{12} 2022$ the existing evidence from human studies is less clear. ${ }^{14}$ Practically, initiating cooling in the prehospital environment is challenging; however, several studies have shown that initiating cooling in the ED is feasible and effective. ${ }^{27} 2831$ The different cooling modalities are shown in table 3. The use of ice packs is a simple, but relatively slow, means of cooling. A bolus of cold intravenous fluids combines efficacy with ease of use and is not associated with significant unwanted side effects. This is probably the cooling method of choice for the ED. Intravenous fluids can be stored in a refrigerator within the ED and administered to patients following OHCA shortly after arrival in hospital. Initiating cooling in the ED is likely to shorten the time to target temperature, particularly if the patient requires coronary intervention or radiological imaging prior to ICU admission. Cooling with cold intravenous fluids can continue during transfer or during clinical procedures.

The three phases of therapeutic hypothermia are induction, maintenance and rewarming. For all phases, accurate core body temperature measurement is essential to ensure accurate cooling and prevent overcooling. For rapid induction, oesophageal or central venous temperature should be measured, as probes in the bladder or rectum do not reflect core body temperature accurately. ${ }^{35}$ Overcooling is common. ${ }^{30}$ After induction, therapeutic hypothermia can be maintained on the ICU with body surface cooling techniques with accurate feedback mechanisms, or invasive, endovascular cooling techniques. In order to prevent shivering, paralysis and sedation are required. The optimum length of time for which MTH should be maintained remains unknown, ${ }^{11} 36$ but previous studies have used maintenance periods of $12-48 \mathrm{~h}^{2}{ }^{3}$ The optimum means, whether active or passive, and rate of warming are unknown, and further research is required to improve the induction, maintenance and rewarming phases.

Despite strong evidence suggesting benefit, uptake of therapeutic hypothermia in routine clinical practice has been slow. ${ }^{10} 37$ Lack of awareness, fear of a novel treatment and unknown side effects, as well as lack of equipment, have been cited as barriers to MTH implementation. ${ }^{38}$

\section{CONCLUSION}

The use of MTH in patients who remain comatose after OHCA improves survival and neurological outcome. The optimal time of initiation, cooling method and target temperature have yet to be established. Cooling is feasible within the ED, and cold intravenous crystalloid infusion is effective, simple and safe. Wider awareness among ED medical staff may increase the early use of therapeutic hypothermia in patients after OHCA.

\section{Competing interests None.}

Provenance and peer review Not commissioned; externally peer reviewed.

\section{REFERENCES}

1. de Vreede-Swagemakers JJ, Gorgels AP, Dubois-Arbouw WI, et al. Out-of-hospital cardiac arrest in the 1990's: a population-based study in the Maastricht area on incidence, characteristics and survival. J Am Coll Cardiol 1997;30:1500-5.

2. Bernard SA, Gray TW, Buist MD, et al. Treatment of comatose survivors of out-ofhospital cardiac arrest with induced hypothermia. N Engl J Med 2002;346:557-63.

3. Hypothermia after Cardiac Arrest Study Group. Mild therapeutic hypothermia to improve the neurologic outcome after cardiac arrest. $N$ Engl J Med 2002;346:549-56.

4. Safar P, Tisherman SA, Behringer W, et al. Suspended animation for delayed resuscitation from prolonged cardiac arrest that is unresuscitable by standard cardiopulmonary-cerebral resuscitation. Crit Care Med 2000;28(11 Suppl): N214-18.

5. Safar P, Abramson NS, Angelos M, et al. Emergency cardiopulmonary bypass for resuscitation from prolonged cardiac arrest. Am J Emerg Med 1990:8:55-67.

6. Bernard SA, Jones BM, Horne MK. Clinical trial of induced hypothermia in comatose survivors of out-of-hospital cardiac arrest. Ann Emerg Med 1997;30:146-53.

7. Yanagawa $\mathbf{Y}$, Ishihara $\mathrm{S}$, Norio $\mathrm{H}$, et al. Preliminary clinical outcome study of mild resuscitative hypothermia after out-of-hospital cardiopulmonary arrest. Resuscitation 1998; 39:61-6.

8. Nolan JP, Morley PT, Hoek TL, et al. Therapeutic hypothermia after cardiac arrest. An advisory statement by the Advancement Life support Task Force of the International Liaison committee on Resuscitation. Resuscitation 2003:57:231-5.

9. Nolan JP, Neumar RW, Adrie C, et al. Post-cardiac arrest syndrome: epidemiology, pathophysiology, treatment, and prognostication. A Scientific Statement from the International Liaison Committee on Resuscitation; the American Heart Association Emergency Cardiovascular Care Committee; the Council on Cardiovascular Surgery and Anesthesia; the Council on Cardiopulmonary, Perioperative, and Critical Care; the Council on Clinical Cardiology; the Council on Stroke. Resuscitation 2008;79:350-79

10. Merchant RM, Soar J, Skrifvars MB, et al. Therapeutic hypothermia utilization among physicians after resuscitation from cardiac arrest. Crit Care Med 2006;34:1935-1940.

11. Nolan JP, Hazinski MF, Steen PA, et al. Controversial topics from the 2005 International Consensus Conference on cardiopulmonary resuscitation and emergency cardiovascular care science with treatment recommendations. Resuscitation 2005;67:175-9.

12. Zhao D, Abella BS, Beiser DG, et al. Intra-arrest cooling with delayed reperfusion yields higher survival than earlier normothermic resuscitation in a mouse model of cardiac arrest. Resuscitation 2008;77:242-9.

13. Sterz F, Safar P, Tisherman S, et al. Mild hypothermic cardiopulmonary resuscitation improves outcome after prolonged cardiac arrest in dogs. Crit Care Med 1991:19:379-89.

14. Wolff B, Machill K, Schumacher D, et al. Early achievement of mild therapeutic hypothermia and the neurologic outcome after cardiac arrest. Int J Cardiol 2009;133:223-8

15. Holzer M, Behringer W. Therapeutic hypothermia after cardiac arrest and myocardia infarction. Best Pract Res Clin Anaesthesiol 2008;22:711-28.

16. Holzer M, Bernard SA, Hachimi-Idrissi S, et al. Hypothermia for neuroprotection after cardiac arrest: systematic review and individual patient data meta-analysis. Crit Care Med 2005;33:414-18.

17. Cheung KW, Green RS, Magee KD. Systematic review of randomized controlled trials of therapeutic hypothermia as a neuroprotectant in post cardiac arrest patients. CJEM 2006;8:329-37.

18. Jadad AR, Moore RA, Carroll D, et al. Assessing the quality of reports of randomized clinical trials: is blinding necessary? Control Clin Trials 1996;17:1-12.

19. Safar P. Resuscitation from clinical death: pathophysiologic limits and therapeutic potentials. Crit Care Med 1988;16:923-41.

20. Kuboyama K, Safar P, Radovsky A, et al. Delay in cooling negates the beneficial effect of mild resuscitative cerebral hypothermia after cardiac arrest in dogs: a prospective, randomized study. Crit Care Med 1993;21:1348-58.

21. Nozari A, Safar P, Stezoski SW, et al. Mild hypothermia during prolonged cardiopulmonary cerebral resuscitation increases conscious survival in dogs. Crit Care Med 2004;32:2110-16.

22. Abella BS, Zhao D, Alvarado J, et al. Intra-arrest cooling improves outcomes in a murine cardiac arrest model. Circulation 2004;109:2786-91. 
23. Weinrauch V, Safar P, Tisherman S, et al. Beneficial effect of mild hypothermia and detrimental effect of deep hypothermia after cardiac arrest in dogs. Stroke 1992;23:1454-62.

24. Williams GR Jr., Spencer FC. The clinical use of hypothermia following cardiac arrest. Ann Surg 1958;148:462-8.

25. Zeiner A, Holzer M, Sterz F, et al. Mild resuscitative hypothermia to improve neurological outcome after cardiac arrest. A clinical feasibility trial. Hypothermia After Cardiac Arrest (HACA) Study Group. Stroke 2000;31:86-94.

26. Felberg RA, Krieger DW, Chuang $\mathrm{R}$, et al. Hypothermia after cardiac arrest: feasibility and safety of an external cooling protocol. Circulation 2001;104:1799-804

27. Bernard S, Buist M, Monteiro 0, et al. Induced hypothermia using large volume, icecold intravenous fluid in comatose survivors of out-of-hospital cardiac arrest: a preliminary report. Resuscitation 2003;56:9-13.

28. Kim F, Olsufka M, Carlbom D, et al. Pilot study of rapid infusion of $2 \mathrm{~L}$ of 4 degrees $\mathrm{C}$ normal saline for induction of mild hypothermia in hospitalized, comatose survivors of out-of-hospital cardiac arrest. Circulation 2005;112:715-19.

29. Busch M, Soreide E, Lossius HM, et al. Rapid implementation of therapeutic hypothermia in comatose out-of-hospital cardiac arrest survivors. Acta Anaesthesiol Scand 2006:50:1277-83.

30. Merchant RM, Abella BS, Peberdy MA, et al. Therapeutic hypothermia after cardiac arrest: unintentional overcooling is common using ice packs and conventional cooling blankets. Crit Care Med 2006;34(12 Suppl):S490-4.

31. Kliegel A, Janata A, Wandaller C, et al. Cold infusions alone are effective for induction of therapeutic hypothermia but do not keep patients cool after cardiac arrest. Resuscitation 2007:73:46-53.
32. Hachimi-Idrissi S, Corne L, Ebinger G, et al. Mild hypothermia induced by a helmet device: a clinical feasibility study. Resuscitation 2001;51:275-81.

33. Laurent I, Adrie C, Vinsonneau C, et al. High-volume hemofiltration after out-ofhospital cardiac arrest: a randomized study. J Am Coll Cardiol 2005:46:432-7.

34. Kim F, Olsufka M, Longstreth WT Jr., et al. Pilot randomized clinical trial of prehospital induction of mild hypothermia in out-of-hospital cardiac arrest patients with a rapid infusion of 4 degrees $C$ normal saline. Circulation 2007:115:3064-70.

35. Stone JG, Young WL, Smith CR, et al. Do standard monitoring sites reflect true brain temperature when profound hypothermia is rapidly induced and reversed? Anesthesiology 1995;82:344-51

36. Gazmuri RJ, Nadkarni VM, Nolan JP, et al. Scientific knowledge gaps and clinical research priorities for cardiopulmonary resuscitation and emergency cardiovascular care identified during the 2005 International Consensus Conference on ECC [corrected] and CPR science with treatment recommendations: a consensus statement from the International Liaison Committee on Resuscitation (American Heart Association, Australian Resuscitation Council, European Resuscitation Council, Heart and Stroke Foundation of Canada, InterAmerican Heart Foundation, Resuscitation Council of Southern Africa, and the New Zealand Resuscitation Council); the American Heart Association Emergency Cardiovascular Care Committee; the Stroke Council; and the Cardiovascular Nursing Council. Circulation 2007:116:2501-12

37. Laver SR, Padkin A, Atalla A, et al. Therapeutic hypothermia after cardiac arrest: a survey of practice in intensive care units in the United Kingdom. Anaesthesia 2006;61:873-7.

38. Acosta $\mathbf{P}$, Varon J. Therapeutic hypothermia-from the bench to the bedside: are we there yet? Resuscitation 2008;79:183-4. 